ADAm ANDRZeJ ZająC

Cardinal Stefan Wyszyński University

in Warsaw, Poland

\section{Michat Witold WiELECHOWSKI}

Warsaw University of Life Sciences,

Poland
Katarzyna Czech

Warsaw University of Life Sciences,

Poland

michal_wielechowski@sggw.edu.pl

\title{
THE IMPACT OF COVID-19 PANDEMIC ON CREDIT FINANCING OF MICROENTERPRISES AND FARMER BUSINESS ACTIVITY IN POLAND
}

\begin{abstract}
The novel coronavirus pandemic has hit the Polish economy, including business activity. The paper aims to assess the impact of COVID-19 on the credit financing of microenterprises and farmers in Poland. We analyse investment loans and working capital loans, particularly the changes in the number and value of these loans, the number of loan enquiries, and the share of non-performing loans.

The research period covers the two-year period, including the pre-COVID-19 subperiod from March 2019 till February 2020 and the COVID-19 subperiod from March 2020 till February 2021. We obtain monthly data from BIK. The BIK Group is the main source of credit and economic information in Poland. The study reveals a significant decrease in the number and value of investment loans and working capital loans during the COVID-19 period compared to the pre-COVID-19 period both in groups of microenterprises and farmers. Surprisingly, despite the difficult time for entrepreneurs, the COVID-19 pandemic significantly reduced the number of loans enquiries. As we expected, the number and value of non-performing loans increase due to the COVID-19 pandemic. However, the value of non-performing investment loans in the group of microenterprises increased marginally.Our research can be helpful for decision-makers and credit market participants, including national governments, financial market supervisory institutions, banks, and micro-entrepreneurs, and farmers.
\end{abstract}

KEYWORDS: COVID-19 pandemic, microenterprises, farmers, investment loans, working capital loans, loan enquiries, non-performing loans 


\section{INTRODUCTION}

According to Ayyagari et al. (2007), Erdogan (2018), and Xia and Gan (2020), small and microenterprises play a key role in the economy, i.e., these firms represent all aspects of people's livelihood, play an important role in GDP creation and taxation, provide jobs, and become a powerhouse in the development of the real economy, and are important contributors to dynamic private sector development. According to the legislation of the European Union, agricultural holdings are considered to be enterprises (European Commission, 2014). The vast majority of Polish farms, due to their size, should be treated as micro-enterprises. Due to the great importance of the SME sector for the development of entrepreneurship and the entire Polish and European economy, numerous studies have analysed the impact of the financial and economic crisis on the activities of these economic entities (Nastase \& Kajanus, 2009; Kola-Bezka, 2011; Czerwińska-Lubszczyk \& Michna, 2013). Empirical studies pay attention to such aspects of the functioning of SMEs as a decrease in sales revenues, significant delays in the collection of receivables, the resulting lack of financial liquidity, deteriorating credit conditions, or the phenomenon of bankruptcy of enterprises (Bourletidis \& Triantafyllopoulos, 2014; Dias et al., 2021; Paulet et al., 2014).

In business activity, particularly microenterprises, it is essential to use foreign capital, both in investment and current activities. Access to bank financing is recognized as crucial to small and microenterprises performance, i.e., their operation, survival, and expansion (Vasilescu, 2014). Agriculture like any other economic activity requires financial capital to boost productivity and income (Jumpah et al., 2019). Bank lending during economic crises has been a subject of intense scrutiny (Hasan et al., 2020), as the disrupted credit allocation process leads to restricted credit supply and higher borrowing costs (Bernanke, 1983). According to Kauko et al. (2021), both the global financial crisis, 2008-2009, and the COVID-19 pandemic have triggered a substantial decline in banks' new lending. It mainly concerns the initial phase of the crisis when companies reduce or postpone their investments in a remarkably uncertain operating environment. 
The paper deals with analysing of the credit market during the recent crisis, i.e., the COVID-19 pandemic. COVID-19 belong to infectious diseases and is caused by SARS-CoV-2 - the severe acute respiratory syndrome coronavirus 2 (Andersen et al., 2020). WHO classified COVID-19 as a global pandemic on 11 March 2020 (Maier \& Brockmann, 2020). Since the pandemic's beginning until 03 August 2021, more than 200 million lab-confirmed COVID-19 cases have been reported worldwide, causing 4.26 million deaths. From the global health crisis (Bavel et al., 2020), the novel coronavirus pandemic has rapidly evolved into a global meltdown (Aggarwal et al., 2020). The COVID-19 pandemic has hit the global economies and societies on an unprecedented scale since the Great Depression or the Global Financial Crisis, and from the epidemic perspective is compared to the Spanish flu pandemic (Barro et al., 2020; Laing, 2020). During the first wave of the novel coronavirus pandemic, national governments implemented countless policies in reaction to it. Cheng et al. (2020) observed over 13,000 such policy announcements across more than 195 countries. COVID-19 impact is more significant among microenterprises than its larges counterparts (Fabeil et al., 2020). Although the agricultural sector is positioned better than most other branches of the economy, many risks need to be managed during the novel coronavirus period (Ker, 2020). The potential vulnerability and resistance of SMEs to the outbreak of the COVID-19 pandemic has been a primary concern for policymakers worldwide (Gourinchas et al., 2020).

The research conducted in the study concerns microenterprises and farmers. In consequence of the COVID-19 outbreak, a great many small and medium-sized enterprises have found themselves in a tough situation and should be supported through, i.e., special credit lines, reduced interest rates on loans, deferred repayments, and the establishment of long-term credit systems (Wu \& Olson, 2020). Bigsten et al. (2003) and Cowling et al. (Cowling et al., 2012) show that micro or small firms are much less likely to get a banking loan than large enterprises, particularly during crisis periods. It seems justified to investigate the impact of the COVID-19 pandemic on the market of loans for microenterprises and farmers in Poland in 2020. According to Falagiarda et al. (Falagiarda et al., 2020). In the European Union, enterprises' demand for bank credits has escalated since the COVID-19 outbreak as firms have scrambled to 
bridge liquidity gaps originating from the novel pandemic shock. Thus, most national governments have implemented schemes of public guarantees on bank credits to transfer part of arising credit risk and potential credit losses from banks to the government. According to Kauko et al. (Kauko et al., 2021), both the global financial crisis, 2008-2009 and the COVID-19 pandemic have triggered a substantial decline in new lending of banks. It mainly concerns the initial phase of the crisis when companies reduce or postpone their investments in a remarkably uncertain operating environment.

The key factors influencing the demand for credit among enterprises are the level of economic activity, the level of interest rates, and the size of the investment activity of enterprises (Calza et al., 2003). COVID-19 has increased the uncertainty among enterprises, which is why we expect an increase in the demand for loans from entrepreneurs.

Dimitrios et. (Dimitrios et al., 2016) claim that euro-area banks suffer from increasing losses due to non-performing loans. Beck et al. (Beck et al., 2015), using panel data from 75 countries worldwide, reveal that share of non-performing loans substantially increase during global financial crisis 2008-2009. Ertas et al. (Ertaş et al., 2021), based on the data about Turkish enterprises, show that entrepreneurs face difficulties in repaying and recovering loans during crisis periods. Liu et al. (2020) also reveal that non-performing loans of EU and BRICS countries have substantially increased after the global financial crisis 2008-2009.

Our contribution is that we are the first to examine the impact of COVID-19 on the market of loans granted to micro-entrepreneurs and farmers. We emphasise that we examine not only the change in the number and value of the investment and working capital loans but also crucial credit indicators, including loan enquiries and the share of non-performing loans, measured by the DPD90 ratio. Moreover, most studies related to the credit market focus on SMEs (small and medium-sized enterprises) or large enterprises, while we analyse the credit market of microenterprises and farmers. The data we use are not publicly available. We obtained them from BIK. Our research can be helpful for decision-makers and credit market participants, including national governments, financial market supervisory institutions, banks, and micro-entrepreneurs, and farmers. 
The paper is organised as follows. The next presents a description of the material and research methods used. The posterior section sets out the empirical findings and discussion, and the final section offers our conclusion.

\section{MeTHODOLOGY}

The main aim of the paper is to assess the impact of COVID-19 on the credit financing of microenterprises and farmers in Poland.

According to the Act on Entrepreneurs Law (2018), a micro-entrepreneur is an entrepreneur who in at least one of the last two financial years met the following conditions, i.e., employed an average of fewer than 10 employees and achieved an annual net turnover from the sale of goods, products, services, and financial operations, not exceeding the PLN equivalent of EUR 2 million or the total assets of its balance sheet prepared at the end of one of these years, did not exceed the PLN equivalent of EUR 2 million. According to the data of Statistics Poland (Statistics Poland, 2019), the number of microenterprises in 2018 in Poland amounted to 2,078,000, which accounted for almost 97\% of all enterprises, excluding agricultural holdings.

According to the EU definition of an enterprise, entities conducting agricultural activity are also classified as enterprises. SME classification is also used for farms. According to the preliminary results of the General Agricultural Census in 2020, Polish farms constitute a large group of entities conducting economic activity; the total number of farms amounted to approx. 1,317 thousand. Thus, farms represent an important group of borrowers for the financial sector. The significance of farms, the basic production unit in agriculture, for the Polish economy and society is indisputable.

In our analysis we consider investment loans and working capital loans. We define investment loans as loans for enterprises intended for a specific purpose related to the financing of new or increasing the existing production and service capacities of the borrower and other joint and accompanying investments, granted for the financing of projects aimed at replacement, modernization, and increase of fixed assets, including financing planned investments, expansion 
of the enterprise, purchase of a machine park or creation of a new production line. Working capital loans are loans for enterprises, granted for any purpose related to the day-to-day operations of a company or a farm, e.g., revolving loans and overdraft facilities.

We study the investment loans and working capital loans for microenterprises and farmers from the perspective of their number, value, number of loan enquiries, and the share of non-performing loans. A number of bank loan enquiries are presented on the basis of requests for a credit report for a given business entity in BIK. A bank credit report is collected when the customer has submitted an application to the bank for a new loan product or an increase in the loan amount. Based on the report, the entity granting the financing receives information on, among others: the amount of all credit obligations held by the client, the history of the client's credit obligations, assessment of the client's creditworthiness, and assessment of the client's credit activity (Woźniak et al., 2012). The number of credit enquiries illustrates the potential demand for credit reported by entrepreneurs.

In line with the methodology used by supervisors of the banking sector, loans for which contractual payments are delayed by a certain number of days are classified as irregular (Basel Committee on Banking Supervision, 2012). According to the recommendation of the Polish Financial Supervision Authority (PFS, 2011), a delay in loan repayment of more than 90 days is one of the objective reasons for its impairment. Therefore such a loan can be classified as non-performing. In banking, a frequently used risk measure representing the share of loans with delay in the entire loan portfolio is the Days-Past-Due (DPD) ratio. The share of non-performing loans is frequently determined by the DPD90+, i.e., loans with more than 90 days overdue.

We obtain monthly data from BIK. BIK is the largest collection of data on individual clients and entrepreneurs in Poland. It has information about the credit history of a total of 1.4 million companies, farmers, and other entities, including 845 thousand. microenterprises. According to the Act of Banking Law, BIK was established in 1997 by banks and the Polish Bank Association (BIK, 2021).

To our knowledge, there are no other research studies that use these data in the credit market analysis from the COVID-19 perspective. 
The research period covers the two-year period, including the pre-COVID-19 subperiod from March 2019 till February 2020 and the COVID-19 subperiod from March 2020 till February 2021.

We apply the two-sample t-test (Snedecor \& Cochran, 1989) to assess whether the mean values of analysed credit measures differ significantly in two analysed periods.

$$
t=\frac{\bar{X}_{N C}-\bar{X}_{C}-\Delta}{\sqrt{\frac{s_{N C}^{2}}{n_{N C}}+\frac{s_{C}^{2}}{n_{C}}}}
$$

Where refers $X_{N C}$ to the mean values of individual credit measures in preCOVID-19 (NC) and $X_{C}$ represents the mean values of applied variables in the COVID-19 period $(C), \Delta$ is the hypothesized difference between the population means (zero if equal means are assumed), $s_{N C}$ and $s_{C}$ are the standard deviations of the two analysed samples, and $n_{N C}$ and $n_{C}$ are numbers of observations in samples. The data are paired. Thus, we assume that there is a one-to-one correspondence between the values in the two samples. That is, if $X_{N C_{1}}, X_{N C_{2}}, \ldots, X_{N C_{n}}$ and $X_{C_{1}}, X_{C_{2}}, \ldots, X_{C_{2}}$ are the two samples, then $X_{N C_{i}}$ corresponds to $X_{C_{i}}$

To achieve the goal of the paper, we formulate four research hypotheses.

Kauko et al. (2021) show that during the crisis period are reluctant to grant loans due to higher credit risk. It implies the potential decrease in the number and value of credit granted to enterprises, particularly microenterprises (Cowling et al., 2012). On the other hand, national governments have implemented schemes of public guarantees on bank credits to transfer part of arising credit risk and potential credit losses from banks to governments (Falagiarda et al., 2020). It may suggest that banks should not limit their credit lines for enterprises. In our opinion, the time of COVID-19 resulted in a decrease in the number of investment and working capital loans granted to microentrepreneurs and farmers. Thus, we put forward the first research hypothesis as follows: 
Hypothesis I: During the COVID-19 period, the number and value of credits have significantly decreased both in group of microenterprises and farmers.

In the applied t-test the null and alternative hypotheses are as follows:

$$
\begin{aligned}
& H O_{I}: \mu_{N C}=\mu_{C} \\
& H O_{I}: \mu_{N C}>\mu_{C}
\end{aligned}
$$

where $\mu \mathrm{NC}$ and $\mu \mathrm{C}$ represent the mean values of individual credit measures in pre-COVID-19 (NC) and COVID-19 period (C), respectively. The null hypothesis assumes that the analysed banking loans measures do not differ in both analysed periods. It implies that COVID-19 has not affected the banking loan market in the group of microenterprises and farmers in Poland.

On the other hand, the crisis time is a period of intensified demand for credit for enterprises (Falagiarda et al., 2020). During COVID-19, national governments have implemented restrictions that hamper business activity in many branches of the economy (Czech et al., 2020). It implies that during the COVID-19 pandemic should be more loan enquiries, particularly WCC. However, the time of crisis is not conducive to undertaking new investments in the enterprise. Thus, we put forward the following two research hypotheses:

Hypothesis II: The COVID-19 pandemic has caused a decrease in the number of investment loan enquiries.

In the applied t-test, the null and alternative hypotheses are as follows:

$$
\begin{aligned}
& H O_{I I}: \mu_{N C}=\mu_{C} \\
& H O_{I I}: \mu_{N C}>\mu_{C}
\end{aligned}
$$

Hypothesis III: The COVID-19 pandemic has caused an increase in the number of working capital loan enquiries.

In the applied t-test, the null and alternative hypotheses are as follows:

$$
\begin{aligned}
& H O_{I I I}: \mu_{N C}=\mu_{C} \\
& H 0_{I I I}: \mu_{N C}<\mu_{C}
\end{aligned}
$$

Despite government assistance programs, due to the accumulating financial problems of enterprises, we assume an increase in the number and value of non-performing loans in the aftermath of the COVID-19 pandemic (Ertaş et al., 2021; Liu et al., 2020). We put forward the following research hypothesis. 
Hypothesis IV: The COVID-19 pandemic has caused the increase in the share of non-performing loans, measured by the DPD90+ ratio.

In the applied t-test, the null and alternative hypotheses are as follows:

$$
\begin{aligned}
& H 0_{I V}: \mu_{N C}=\mu_{C} \\
& H O_{I V}: \mu_{N C}<\mu_{C}
\end{aligned}
$$

As we consider farmers to be entrepreneurs, our study assumes that the impact of COVID-19 on microenterprises and farmers is similar.

\section{RESEARCH RESULTS}

The outbreak of the COVID-19 pandemic resulted in the introduction of numerous restrictions by the Polish government to stop the novel coronavirus. However, these anti-COVID-19 restrictions have resulted in numerous negative effects on the Polish economy.

The data on daily new laboratory-confirmed cases of COVID-19 in Poland was collected from Refinitiv Datastream. To measure the stringency of the government response to the outbreak of the COVID-19 pandemic, we use data on the Stringency index from the Oxford COVID-19 Government Response Tracker developed by the Blavatnik School of Government (Hale, Webster, et al., 2020a). The index systematically tracks the severity level of government responses to the COVID-19 pandemic in time across more than 150 countries. The Stringency index consists of eight individual government response measures, including school closing, workplace closing, public events cancellations, restrictions on gathering size, public transport closing, stay-at-home requirements, restrictions on internal movements, restrictions on international travel, and public information campaign. The index ranges from 0 to 100 (Hale et al., 2020b). The data in Figure 1 show the evolution of the number of new COVID-19 cases and the severity index from March 2020 to February 2021, i.e., covering the period of two waves of the pandemic. 
Figure 1.

Epidemic status and stringency of government anti-COVID-19 policy in Poland in the period March 2020-February 2021.

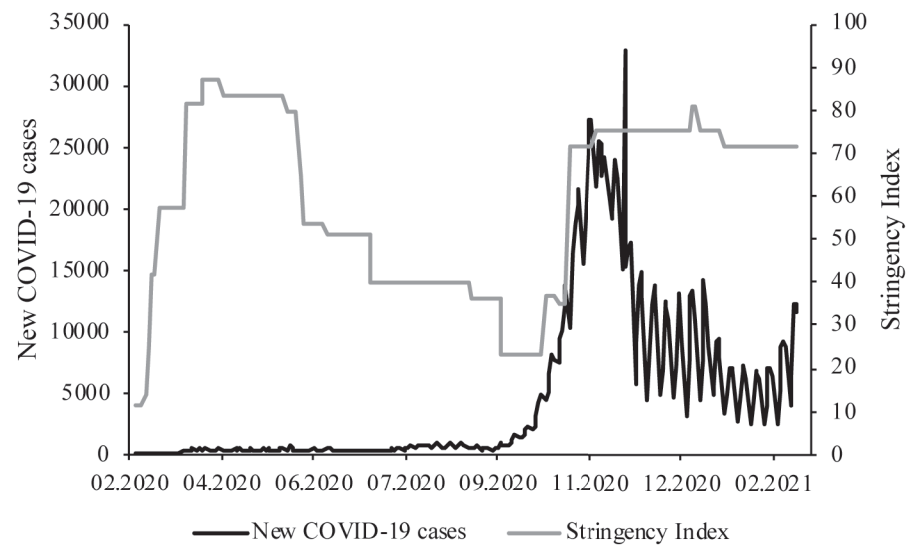

Source: own elaboration based on Refinitiv Datastream.

Compared to other European Union countries, Poland is one of the last countries to experience the outbreak of the COVID-19, as the first lab-confirmed COVID-19 case was observed on 4th March 2020 (Czech et al., 2020). Figure 1 shows that a small number of infections were observed during the first wave, accompanied by stringent restrictions resulting in an almost full lockdown of the entire country. Most sectors of the economy were closed or significantly limited. The second pandemic wave, which occurred in the autumn of 2020, was characterized by a much higher number of disease cases and a similar level of restrictiveness of the government's anti-COVID-19 policy. This shows that during the entire research period, i.e., from March 2020 to February 2021, Polish enterprises operated in unfavourable conditions, typical of the period of the economic crisis. The shock caused by the COVID-19 pandemic and the numerous restrictions introduced by the government to contain the spread of the coronavirus resulted in a significant decline in economic activity, what PMI depicts.

Monthly PMI data are compiled by IHS Markit (2021) for 40 countries around the world. The Manufacturing PMI index is based on the results of surveys of senior management in private-sector manufacturing companies. 
The PMI index ranges from 0 to 100 . PMI values above 50 points indicate an economic expansion. More respondents then declare an improvement in the economic situation. On the other hand, index values below 50 mean deteriorating sentiment among enterprises and reflect deteriorating economic conditions in the national economy. Figure 2 shows the Manufacturing Purchasing Managers' Index development in Poland from March 2019 to February 2021, i.e., in the pre-COVID-19 and COVID-19 periods.

Figure 2.

PMI index for Poland in the period March 2019-February 2021.

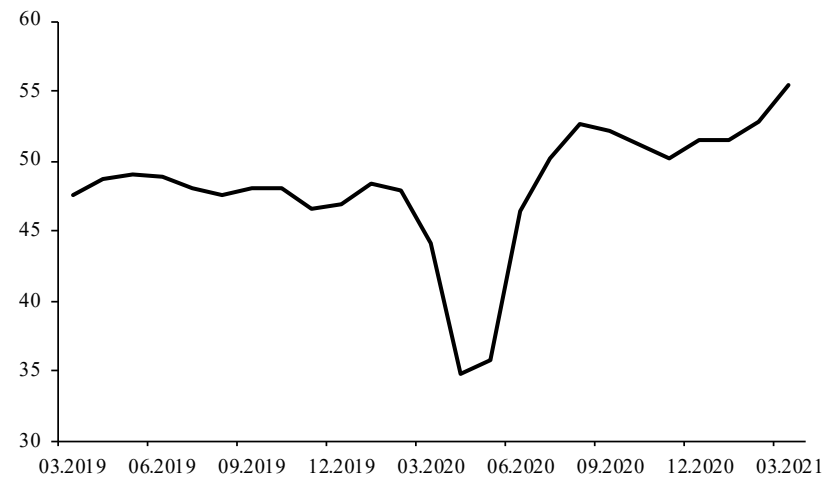

Source: own elaboration based on Refinitiv Datastream.

Figure 2 shows that the PMI for the industry has plummeted as a result of the COVID-19 pandemic in Poland. In March 2020, it reached the value of 44.1, which is 3.8 points less than in February 2020. However, the lowest value of the index was recorded in April 2020, when it fell to 34.8. The PMI for manufacturing below 50 points reflects the shrinkage of the manufacturing sector and, consequently, the slowdown in economic growth and risk of recession. According to Mitręga-Niestrój (2012), a PMI below 40 is already a sign of a serious crisis related to the loss of liquidity by contractors. It is worth adding that as a result of the COVID-19 pandemic, the global PMI index fell to levels similar to those it achieved during the global financial crisis of 2008-2009 (Lorenzo \& Lean, 2020). Unexpectedly, the second wave of the pandemic and the accompanying restrictions did not reduce the optimism of entrepreneurs. The PMI level was above 50 points by the end of the analysed period. 
We have revealed the negative impact of COVID-19 on the sentiment of Polish entrepreneurs, primarily in the initial phase of the novel coronavirus pandemic. It corresponds to Kauko et al. (2021). However, the economic risk index developed by Oxford Economics shows that the level of economic, financial, business, and market risk remained unchanged between the preCOVID-19 and COVID-19 periods (Czech et al., 2020). Moreover, Kauko et al. (2021) reveal that the COVID-19 pandemic has triggered a substantial decline in banks' new lending. Table 1 presents the statistical measures related to the number and values of investment loans and working capital loans for microenterprises and farmers.

Table 1.

Investment loans and working capital loans for microenterprises and farmers in pre-COVID-19 and COVID-19 years: t-test analysis

\begin{tabular}{|c|c|c|c|c|c|c|c|}
\hline \multirow{2}{*}{ Variable } & \multicolumn{2}{|c|}{ Mean value (in thous.) } & \multicolumn{2}{|c|}{ Standard deviation } & \multirow{2}{*}{$\begin{array}{c}\mathrm{T} \text { test } \\
\text { statistic }\end{array}$} & \multirow{2}{*}{$\begin{array}{c}\text { p-value } \\
\text { (one- } \\
\text { sided) } \\
\end{array}$} & \multirow{2}{*}{$\begin{array}{c}\text { p-value } \\
\text { (two- } \\
\text { sided) } \\
\end{array}$} \\
\hline & NONCOVID & COVID & NONCOVID & COVID & & & \\
\hline $\begin{array}{l}\text { IL_Micro_ } \\
\text { No }\end{array}$ & 1022.60 & 757.49 & 131.32 & 135.52 & 4.68 & $<0.001$ & 0,001 \\
\hline $\begin{array}{l}\text { IL_Micro_ } \\
\text { Value }\end{array}$ & 367.04 & 241.11 & 67.91 & 55.86 & 4.87 & $<0.001$ & $<0.001$ \\
\hline $\begin{array}{l}\text { IL_Farmer_ } \\
\text { No }\end{array}$ & 1373.08 & 1039.12 & 279.63 & 285.94 & 4.68 & $<0.001$ & $<0.001$ \\
\hline $\begin{array}{l}\text { IL_Farmer_ } \\
\text { Value }\end{array}$ & 296.85 & 244.60 & 56.69 & 52.79 & 4.87 & 0,001 & 0,001 \\
\hline $\begin{array}{l}\text { WCL_ } \\
\text { Micro_No }\end{array}$ & 5254.12 & 3486.49 & 536.49 & 654.79 & 8.13 & $<0.001$ & $<0.001$ \\
\hline $\begin{array}{l}\text { WCL }_{-} \\
\text {Micro_ } \\
\text { Value }\end{array}$ & 758.14 & 559.01 & 83.54 & 102.01 & 7.44 & $<0.001$ & $<0.001$ \\
\hline $\begin{array}{l}\text { WCL_} \\
\text { Farmer_No }\end{array}$ & 3833.62 & 2746.82 & 1374.16 & 1130.63 & 4.91 & $<0.001$ & $<0.001$ \\
\hline $\begin{array}{l}\text { WCL_ } \\
\text { Farmer_ } \\
\text { Value }\end{array}$ & 212.80 & 168.63 & 68.59 & 61.83 & 2.50 & 0,015 & 0,029 \\
\hline
\end{tabular}

Source: own calculation based on BIK data.

In the first research hypothesis, we assume that both the number and value of an investment and working capital loans have decreased as a consequence of 
the COVID-19 pandemic outbreak. Descriptive statistics presented in Table 1 support our assumption. In the case of investment loans, their number has decreased by approximately a quarter both for microenterprises and farmers. In terms of the value of investment loans, a decrease was also observed, but it amounted to approx. in the group of farmers. 17.5\%, while in the group of micro-entrepreneurs it was almost twice as high. In working capital loans, a significant decrease in the number and value of loans was also observed due to the COVID-19 pandemic, both for microenterprises and farmers. Higher, by 5-6 percentage points, negative changes concern micro-entrepreneurs.

We apply t-test to verify the null hypothesis that mean values of analysed bank loan measures do not differ significantly between the pre-COVID-19 and COVID-19 period, i.e., $H_{0}: \mu_{N C}=\mu_{C}$. Table 1 results show that at a $5 \%$ significance level, we reject the null hypothesis. It implies that the average values of investment loans and working capital loans differ significantly in both periods (two-sided p-value lower than 5\%) and are significantly lower in the COVID-19 period (one-sided p-value lower than 5\%). Positive values of t-test statistics imply the decrease of the analysed variables in the research periods. Based on the above research results, we can confirm the research hypothesis I. Table 2.

Enquiries for investment loans and working capital loans in the group of microenterprises and farmers in pre-COVID-19 and COVID-19 years: t-test analysis

\begin{tabular}{|l|c|c|c|c|c|c|c|}
\hline \multirow{2}{*}{ Variable } & \multicolumn{2}{|c|}{ Mean value (in thous.) } & \multicolumn{2}{c|}{ Standard deviation } & $\begin{array}{c}\text { T test } \\
\text { statistic }\end{array}$ & $\begin{array}{c}\text { p value } \\
\text { (one- } \\
\text { sided) }\end{array}$ & $\begin{array}{c}\text { p-value } \\
\text { (two- } \\
\text { sided) }\end{array}$ \\
\cline { 2 - 7 } & NONCOVID & COVID & NONCOVID & COVID & & & \\
\hline $\begin{array}{l}\text { IL_E_ } \\
\text { Micro }\end{array}$ & 2209,42 & 1368,67 & 497,57 & 307,15 & 4,30 & $<0.001$ & 0,001 \\
\hline $\begin{array}{l}\text { IL_E_ } \\
\text { Farmer }\end{array}$ & 2172,25 & 1171,08 & 458,14 & 252,26 & 9,40 & $<0.001$ & $<0.001$ \\
\hline $\begin{array}{l}\text { WCL_E_ } \\
\text { Micro }\end{array}$ & 15265,83 & 7764,75 & 2842,54 & 1437,10 & 10,14 & $<0.001$ & $<0.001$ \\
\hline $\begin{array}{l}\text { WCL_E_ } \\
\text { Farmer }\end{array}$ & 5712,00 & 4042,17 & 1846,59 & 1369,99 & 5,25 & $<0.001$ & $<0.001$ \\
\hline
\end{tabular}

Source: own calculation based on BIK data. 
Table 2 depicts the statistical measures related to a number of enquiries for investment loans and working capital loans by microenterprises and farmers. In the second research hypothesis, we assume that number of enquiries for investment loans has decreased as a consequence of the COVID-19 pandemic outbreak. Descriptive statistics presented in Table 2 support our assumption. The number of enquiries for investment loans has substantially decreased both in the group of microenterprises and farmers in the COVID-19 period in relation to the pre-COVID-19 period by approximately $38 \%$ and $46 \%$, respectively.

Then, we apply a t-test to verify the null hypothesis that mean values of enquiries for investment loans do not differ significantly between the preCOVID-19 and COVID-19 periods. Table 2 results show that at a 5\% significance level, we reject the null hypothesis. It implies that mean values of enquiries for investment loans differ significantly in both periods (two-sided p-value lower than 1\%) and are significantly lower in the COVID-19 period (one-sided p-value lower than 1\%). It indicates that during the COVID-19 pandemic, the demand for investment loans reported by microenterprises and individual farmers decreased. The decline in demand for investment loans is most likely caused by the postponement of some investments carried out by the analysed groups of enterprises until the post-pandemic time. Based on the above research results, we can confirm research hypothesis II.

In the third research hypothesis, we assume that number of enquiries for working capital loans has increased as a consequence of the COVID-19 pandemic outbreak. Surprisingly, descriptive statistics presented in Table 2 do not support this assumption. As in the case of investment loans, the number of enquiries for working capital loans in the group of microenterprises and farmers significantly decreased in the COVID-19 period compared to the period before COVID-19. However, the magnitude of the decline is visibly different in the two analysed groups of entrepreneurs, i.e., approximately $50 \%$ in microenterprises and $30 \%$ in the group of farmers.

Table 2 results show that we reject the null hypothesis at a 5\% significance level, which assumes that mean values of enquiries for working-capital loans do not differ significantly between pre-COVID-19 and COVID-19 periods. It implies that mean values of enquiries for working capital loans differ significantly in both periods (two-sided p-value lower than 1\%). However, positive 
values of $\mathrm{t}$-test statistics and one-sided $\mathrm{p}$-value lower than $1 \%$ imply that the number of enquiries for working capital loans is significantly lower in the COVID-19 period in relation to the pre-COVID-19 period. The demand for working capital loans, measured by the number of enquiries, also decreased. The reason for this may be the decline in the scale of operations of microenterprises and farmers during the pandemic, which translates into reduced demand for ongoing financing. The higher drop in the number of enquiries in the group of microenterprises indicates that this group reduced its activities to a greater extent during the pandemic. Based on the above research results, we cannot confirm research hypothesis III.

Table 3.

The share of non-performing investment loans and working capital loans in the group of microenterprises and farmers in pre-COVID-19 and COVID-19 years: t-test analysis

\begin{tabular}{|c|c|c|c|c|c|c|c|}
\hline \multirow{2}{*}{ Variable } & \multicolumn{2}{|c|}{ Mean value (in \%) } & \multicolumn{2}{|c|}{ Standard deviation } & \multirow{2}{*}{$\begin{array}{c}\text { T test } \\
\text { statistic }\end{array}$} & \multirow{2}{*}{$\begin{array}{c}\text { p-value } \\
\text { (one-sided) }\end{array}$} & \multirow{2}{*}{$\begin{array}{c}\text { p-value } \\
\text { (two-sided) }\end{array}$} \\
\hline & NONCOVID & COVID & NONCOVID & COVID & & & \\
\hline $\begin{array}{l}\text { IL_DPD90+_ } \\
\text { Micro_No }\end{array}$ & 14,02 & 19,62 & 3,20 & 0,49 & $-5,63$ & $<0.001$ & $<0.001$ \\
\hline $\begin{array}{l}\text { IL_DPD90+_ } \\
\text { Micro_Value }\end{array}$ & 14,55 & 14,87 & 0,43 & 0,30 & $-1,60$ & $<0.001$ & $<0.001$ \\
\hline $\begin{array}{l}\text { IL_DPD90+_ } \\
\text { Farmer_No }\end{array}$ & 2,05 & 2,45 & 0,16 & 0,13 & $-9,43$ & $<0.001$ & $<0.001$ \\
\hline $\begin{array}{l}\text { IL_DPD90+_ } \\
\text { Farmer_ } \\
\text { Value }\end{array}$ & 4,75 & 5,11 & 0,25 & 0,16 & $-5,68$ & $<0.001$ & $<0.001$ \\
\hline $\begin{array}{l}\text { WCL_} \\
\text { DPD90+_ } \\
\text { Micro_No }\end{array}$ & 17,93 & 20,16 & 0,74 & 0,45 & $-9,83$ & $<0.001$ & $<0.001$ \\
\hline $\begin{array}{l}\text { WCL_} \\
\text { DPD90+_- } \\
\text { Micro_Value }\end{array}$ & 19,68 & 22,22 & 0,76 & 0,57 & $-12,46$ & $<0.001$ & $<0.001$ \\
\hline $\begin{array}{l}\text { WCL } \\
\text { DPD90+_- } \\
\text { Farmer_No }\end{array}$ & 3,03 & 3,59 & 0,20 & 0,15 & $-20,76$ & $<0.001$ & $<0.001$ \\
\hline $\begin{array}{l}\text { WCL_ } \\
\text { DPD90+_ } \\
\text { Farmer_ } \\
\text { Value }\end{array}$ & 6,94 & 8,49 & 0,26 & 0,48 & $-10,66$ & $<0.001$ & $<0.001$ \\
\hline
\end{tabular}

Source: own calculation based on BIK data. 
Table 3 shows the statistical measures related to the number and values of non-performing investment loans and working capital loans in the group of microenterprises and farmers. In the fourth research hypothesis, we assume that both the number and value of non-performing investment and working capital loans have increased as a consequence of the COVID-19 pandemic outbreak. Descriptive statistics presented in Table 3 support our assumption. In the case of investment loans, the number of non-performing loans has substantially increased by approximately 40 and $20 \%$ in the group of microenterprises and farmers, respectively. However, in terms of the value of non-performing investment loans, the growth was not so prominent, i.e., we observe an increase by only $2 \%$ in the group of microenterprises and less than $8 \%$ in the case of farmers.

Analysing non-performing working capital loans, we observe an increase in the number and value of these banking loans both in the group of microenterprises and farmers in the COVID-19 period in relation to the pre-COVID-19 period. The growth of number and values of working capital loans is greater in the group of farmers than in microenterprises. We apply a t-test to verify the null hypothesis that mean values of number and values of non-performing investment and working capital loans do not differ significantly between the pre-COVID-19 and COVID-19 periods. Table 3 results show that at a 5\% significance level, we reject the null hypothesis. It implies that the average numbers and values of the analysed banking loans differ significantly in both periods (two-sided p-value lower than 1\%). Moreover, negative values of $\mathrm{t}$-test statistics and one-sided p-value lower than $1 \%$ imply that the number and value of non-performing investment and working capital loans are significantly higher in the COVID-19 period compared to the pre-COVID-19 period. The increase in the number and value of non-performing loans suggests that, as COVID-19-driven decrease in sales revenues, some microenterprises and farmers have lost financial liquidity, i.e. the ability to settle their liabilities on a current basis. Based on the above research results, we can confirm the research hypothesis IV.

The observed decrease in the number and value of new investment and working capital loans in the COVID-19 period compared to the pre-COVID-19 period corresponds to the study of Kauko et al. (2021). We reveal the decrease in 
banking loan demand among analysed groups of enterprises during COVID-19. It confirms the study of Calza et al. (2003) that show that credit demand is affected by changing economic activity during the crisis period. Moreover, we show that COVID-19 has triggered the growth of the number of banking loans at risk. It is in line with Ertas et al. (2021) and Liu et al. (2020), who observed the increase in the share of non-performing loans during crisis periods.

\section{Conclusion}

The novel coronavirus pandemic has hit the Polish economy. To contain the spread of the virus, the Polish government, like other national governments, has implemented a policy of strict restrictions. This contributed to limiting the activities of many sectors of the economy and worsening the sentiment among entrepreneurs, which is reflected in the significant decline in the PMI index for Poland in the first months of the COVID-19 pandemic.

The paper aims to assess the impact of the COVID-19 pandemic on credit financing of microenterprises and farmers' business activity in Poland. Due to the scale of their activities, microentrepreneurs and farmers are particularly vulnerable to the negative consequences of the current pandemic. During the crisis period, banks are reluctant to face the higher risks and are less willing to grant these groups of enterprises.

The study reveals a significant decrease in the number and value of the investment and working capital loans during the COVID-19 period compared to the pre-COVID-19 period. The descriptive statistics indicate that the decline was greater in the group of microenterprises than farmers. Surprisingly, despite the difficult time for entrepreneurs, the COVID-19 pandemic result in a significant reduction in the number of loans enquiries, including investment and working capital loans, in both analysed groups of entrepreneurs. As we expected, the number and value of non-performing loans increase as a consequence of the COVID-19 pandemic. However, the value of non-performing investment loans in the group of microenterprises increases marginally. Our study shows that the novel coronavirus pandemic has significantly affected 
the banking loan market for microenterprises and farmers. We observe a decrease in granted loans and loan enquiries and an increase in the share of non-performing loans.

Our research might be useful for the Polish national government, financial institutions, banks, and entrepreneurs. Due to the short time series, i.e., monthly data from the two-year research period, we are not able to perform the analysis using more advanced statistical methods. Obtaining higher frequency data from a longer period in the future will allow for a more in-depth assessment of the impact of the COVID-19 pandemic on the loan market for microenterprises in Poland. Additionally, future research may consider other groups of enterprises, i.e., small, medium, and large. 


\section{REFERENCES}

Act of 6 March 2018 - Entrepreneurs' Law (Article 7), Journal of Laws 2018 item 646 consolidated text.

Aggarwal, S., Nawn, S., \& Dugar, A. (2020). What caused global stock market meltdown during the COVID pandemic-Lockdown stringency or investor panic? Finance Research Letters, 101827. https://doi.org/10.1016/j.frl.2020.101827

Andersen, K. G., Rambaut, A., Lipkin, W. I., Holmes, E. C., \& Garry, R. F. (2020). The proximal origin of SARS-CoV-2. Nature Medicine, 26(4), 450-452. https://doi. org/10.1038/s41591-020-0820-9

Ayyagari, M., Beck, T., \& Demirguc-Kunt, A. (2007). Small and Medium Enterprises Across the Globe. Small Business Economics, 29(4), 415-434. https://doi.org/10.1007/ s11187-006-9002-5

Barro, R., Ursúa, J., \& Weng, J. (2020). The Coronavirus and the Great Influenza Pandemic: Lessons from the "Spanish Flu" for the Coronavirus's Potential Effects on Mortality and Economic Activity (No. w26866; p. w26866). National Bureau of Economic Research. http://www.nber.org/papers/w26866.pdf

Basel Committee on Banking Supervision, Core Principles for Effective Banking Supervision, September 2012.

Bavel, J. J. V., Baicker, K., Boggio, P. S., Capraro, V., Cichocka, A., Cikara, M., Crockett, M. J., Crum, A. J., Douglas, K. M., Druckman, J. N., Drury, J., Dube, O., Ellemers, N., Finkel, E. J., Fowler, J. H., Gelfand, M., Han, S., Haslam, S. A., Jetten, R. (2020). Using social and behavioural science to support COVID-19 pandemic response. Nature Human Behaviour, 4(5), 460-471. https://doi.org/10.1038/s41562-020-0884-z

Beck, R., Jakubik, P., \& Piloiu, A. (2015). Key Determinants of Non-performing Loans: New Evidence from a Global Sample. Open Economies Review, 26(3), 525-550. https://doi.org/10.1007/s11079-015-9358-8

Bernanke, B. (1983). Non-Monetary Effects of the Financial Crisis in the Propagation of the Great Depression (No. w1054; p. w1054). National Bureau of Economic Research. https://doi.org/10.3386/w1054

Bigsten, A., Collier, P., Dercon, S., Fafchamps, M., Gauthier, B., Gunning, J. W., Oduro, A., Oostendorp, R., Patillo, C., Söderbom, M., Teal, F., \& Zeufack, A. (2003). Credit Constraints

BIK: https://www.bik.pl/o-nas, access: 30.06.2021.

Commission regulation (EU) No 651/2014 of 17 June 2014 declaring certain categories of aid compatible with the internal market in application of Articles 107 and 108 of the Treaty. in Manufacturing Enterprises in Africa. Journal of African Economies, 12(1), 104-125. https://doi.org/10.1093/jae/12.1.104 
Bourletidis, K., \& Triantafyllopoulos, Y. (2014). SMEs Survival in Time of Crisis: Strategies, Tactics and Commercial Success Stories. Procedia - Social and Behavioral Sciences, 148, 639-644. https://doi.org/10.1016/j.sbspro.2014.07.092

Calza, A., Gartner, C., \& Sousa, J. (2003). Modelling the demand for loans to the private sector in the euro area. Applied Economics, 35(1), 107-117. https://doi. org/10.1080/00036840210161837

Cheng, C., Barceló, J., Hartnett, A. S., Kubinec, R., \& Messerschmidt, L. (2020). COVID-19 Government Response Event Dataset (CoronaNet v.1.0). Nature Human Behaviour, 4(7), 756-768. https://doi.org/10.1038/s41562-020-0909-7

Cowling, M., Liu, W., \& Ledger, A. (2012). Small business financing in the UK before and during the current financial crisis. International Small Business Journal, 30(7), 778-800. https://doi.org/10.1177/0266242611435516

Czech, K., Karpio, A., Wielechowski, M., Woźniakowski, T., \& ŻebrowskaSuchodolska, D. (2020). Polska gospodarka w początkowym okresie pandemii COVID-19. WULS-SGGW.

Czerwińska-Lubszczyk, A., \& Michna, A. (2013). SME in economic slowdown. Zeszyty Naukowe Politechniki Śląskiej, Z. 64, 21-31.

Dias, Á. L., Manuel, E. C., Dutschke, G., Pereira, R., \& Pereira, L. (2021). Economic crisis effects on SME dynamic capabilities. International Journal of Learning and Change, 13(1), 63. https://doi.org/10.1504/IJLC.2021.111662

Dimitrios, A., Helen, L., \& Mike, T. (2016). Determinants of non-performing loans: Evidence from Euro-area countries. Finance Research Letters, 18, 116-119. https:// doi.org/10.1016/j.frl.2016.04.008

Erdogan, A. I. (2018). Factors affecting SME access to bank financing: An interview study with Turkish bankers. Small Enterprise Research, 25(1), 23-35. https:/doi. org/10.1080/13215906.2018.1428911

Ertaş, M., Sel, Z. G., Kırlar-Can, B., \& Tütüncü, Ö. (2021). Effects of crisis on crisis management practices: A case from Turkish tourism enterprises. Journal of Sustainable Tourism, 29(9), 1490-1507. https://doi.org/10.1080/09669582.2021.1879818

Fabeil, N. F., Pazim, K. H., \& Langgat, J. (2020). The Impact of COVID-19 Pandemic Crisis on Micro-Enterprises: Entrepreneurs' Perspective on Business Continuity and Recovery Strategy (SSRN Scholarly Paper ID 3612830). Social Science Research Network. https://papers.ssrn.com/abstract $=3612830$

Falagiarda, M., Prapiestis, A., \& Rancoita, E. (2020). Public loan guarantees and bank lending in the COVID-19 period. Economic Bulletin Boxes, 6. https://ideas.repec. org/a/ecb/ecbbox/202000067.html

Gourinchas, P.-O., Kalemli-Özcan, Sebnem, Penciakova, V., \& Sander, N. (2020). COVID-19 and SME Failures (No. w27877; p. w27877). National Bureau of Economic Research. https://doi.org/10.3386/w27877 
Hale, T., Angrist, N., Cameron-Blake, E., Hallas, L., Kira, B., Mjumdar, S., Petherick, A., Phillips, T., Tatlow, H., \& Webster, S. (2020). Variation in government responses to COVID-19. Blavatnik School of Government Working Paper Series, BSG-WP2020/032(Version 8.0), 1-29.

Hale, T., Webster, S., Petherick, A., Phillips, T., \& Kira, B. (2020). Oxford COVID-19 Government Response Tracker. Blavatnik School of Government. www.bsg.ox.ac. uk/covidtracker

Hasan, I., Politsidis, P. N., \& Sharma, Z. (2020). Bank Lending during the COVID-19 Pandemic. SSRN Electronic Journal. https://doi.org/10.2139/ssrn.3711021

IHS Markit: PMITM by HIS Markit. https://ihsmarkit.com/products/pmi.html, access: 29.06.2021.

Jumpah, E. T., Osei-Asare, Y., \& Tetteh, E. K. (2019). Do farmer and credit specific characteristics matter in microfinance programmes' participation? Evidence from smallholder farmers in Ada west and east districts. Agricultural Finance Review, 79(3), 353-370. https://doi.org/10.1108/AFR-05-2018-0044

Kauko, K., Loman, T., Mäki-Fränti, P., Salenius, T., \& Vauhkonen, J. (2021). Moderate growth in Finnish companies' non-performing loans (Bank of Finland Articles on the Economy) [Bank of Finland Bulletin]. Bank of Finland.

Ker, A. P. (2020). Risk management in Canada's agricultural sector in light of COVID-19. Canadian Journal of Agricultural Economics/Revue Canadienne d'agroeconomie, 68(2), 251-258. https://doi.org/10.1111/cjag.12232

Kola-Bezka, M. (2011). SMEs in Poland during the world economic crisis. Zeszyty Naukowe Uniwersytetu Szczecińskiego. Finanse, Rynki Finansowe, Ubezpieczenia, 43, 79-89.

Laing, T. (2020). The economic impact of the Coronavirus 2019 (Covid-2019): Implications for the mining industry. The Extractive Industries and Society, 7(2), 580-582. https://doi.org/10.1016/j.exis.2020.04.003

Liu, L., Liu, Y., \& Kim, J.-M. (2020). Sustainable Visual Analysis for Bank NonPerforming Loans and Government Debt Distress. Sustainability, 12(1), 131. https:// doi.org/10.3390/su12010131

Lorenzo, M., \& Lean, A. (2020). The Economic Impact of COVID-19. IDOSR Journal of Banking, Economics and Social Sciences, 5(1), 45-50.

Maier, B. F., \& Brockmann, D. (2020). Effective containment explains subexponential growth in recent confirmed COVID-19 cases in China. Science, 368(6492), 742-746. https://doi.org/10.1126/science.abb4557

Mitręga-Niestrój, K. (2012). The consequences of the global financila crisis for the real sphere-International perspective. Economic Studies, 122, 159-171. 
Nastase, C., \& Kajanus, M. (2009). The Impact of the Global Crisis on SME and Entrepreneurship Bahavior - Romania and Finland Cases. The Amfiteatru Economic Journal, 11, 751-762.

Paulet, E., Parnaudeau, M., \& Abdessemed, T. (2014). The SME struggle for financing: A clampdown in European banks post-crisis. Journal of Business Strategy, 35(2), 36-45. https://doi.org/10.1108/JBS-09-2013-0089

Polish Financial Supervision Authority, Recommendation R on the principles of identification of balance sheet impaired credit exposures, determination of: impairment losses on balance sheet credit exposures, and provisions for off-balance sheet credit exposures, Warsaw 2011

Snedecor, G. W., \& Cochran, W. G. (1989). Statistical Methods (8th Edition). Iowa State University Press.

Statistics Poland, Activity of Non-Financial Enterprises in 2018, statistical analysis, Warsaw 2019.

Vasilescu, L. (2014). Accessing Finance for Innovative EU SMEs Key Drivers and Challenges. Economic Review: Journal of Economics and Business, 12(2), 35-47.

Woźniak, P., Rogowski, W. (2012). Główne produkty i usługi oferowane przez Biuro Informacji Kredytowej S.A. w: Kurkliński, Lech; Markowski, Krzysztof, Systemy Wymiany Informacji Kredytowej. Doświadczenia polskie i europejskie. Warszawa: Biuro Informacji Kredytowej S.A.

Wu, D. D., \& Olson, D. L. (2020). The Effect of COVID-19 on the Banking Sector. In D. D. Wu \& D. L. Olson (Eds.), Pandemic Risk Management in Operations and Finance: Modeling the Impact of COVID-19 (pp. 89-99). Springer International Publishing. https://doi.org/10.1007/978-3-030-52197-4_8

Xia, X., \& Gan, L. (2020). SME financing with new credit guarantee contracts over the business cycle. International Review of Economics \& Finance, 69, 515-538. https:// doi.org/10.1016/j.iref.2020.04.015 